\title{
PENGERTIAN STRUKTUR DATA
}

\author{
Andry Andaru \\ 155100006 \\ Fakultas Komputer \\ andryandaru.studdent@umitra.ac.id
}

\begin{abstract}
Pemograman dalam struktur data ada beberapa macam. Salah satunyaadalah pemograman $\mathrm{C}++$. Dalam pemograman ini biasanya menggunakanvariable Array, Struktur dan Linked ListMakalah ini membahas tentang 3 variabel tersebut dimana ketiga variablemempunyai ciri dan umum yang berbeda sesuai dengan tipe file yang digunakan pembaca. Seperti array yang menggunakan satu dimensi dan duadimensi serta 3 dimensi dimana sangat berbeda dengan struktur yangmenggunakan tingkatan prosedur.Pemograman ini merupakan pemograman yang berbeda dari pemogramanlainnya misalnya VB, Delphi atau Pascal namun perbedaan juga tidakbegitu signifikan pada pemograman pascal.
\end{abstract}

Kata Kunci : pengertian struktur data

\section{A. PENDAHULUAN}

Untuk membuat menjadi struktur data, kita harus melakukan dulu aktivitasterhadap objek data, yaitu :vMendeskkripsikan kumpulan operasi sah yang diterapkan ke elemen-elemen objek data.vMenunjukan mekanisme kerja operasi-operasi.Objek data integer ditambah operasi $(+,-, *$, /, mod ,cell , floor , <, >) danoperasioperasi lain yang memanipuasi objek data integer menyatakan strukturdata.Struktur data $=$ Objek data $+\{$ Operasi manipulasi \}.Tahap pembuatan struktur data adalah
:ØTahap pertama: SpesifikasiPendeskripsian / spesifikasi struktur data menyatakan apa yang dapatdilakukan struktur data, bukan cara penerapannya.Spesifikasi dapat dilakukan dengan dua cara, yaitu $\therefore$ Spesifikasi secara formal-Spesifikasi secara informalØTahap kedua : ImplementasiImplementasi menyatakan cara penerapan struktur data dengan strukturdata yang telah ada.Implementasi struktur data adalah prosespendefinisian tipe data abstrak sehingga semua operasi dapatdieksekusi computer. Implementasi struktur penyinpanan 
item-item dataserta algoritmaalgoritma untuk implementasi operasioperasi sehinggamenjamin terpenuhinya karakteristik struktur data, relasi item-item dataatau invariant pada struktur data itu.ØTahap ketiga : PemrogramanPemrograman terstruktur adalah penerjemahan menjadi pernyataan dibahasa pemrograman tertentu. Prosesnya terdiri dari $\therefore$ Deklarasi yang mendefinisikan objek-objek data danhubungannya... Pembuatan

prosedur / rutin untuk operasi-operasi dasar yangmenjaga invariant pada struktur data itu .Sesuai dengan relasi yang didefinisikan di spesifikasi perancangan harusmemilih tipe-tipe data yang telah ada untuk merepresentasikan struktur data.Struktur data di bangun menggunakan fasilitas pembentukan ataupembuatan struktur data yang disediakan bahasa seperti array, record, dansebagainya atau yang telah di buat seperti stack, queue, atau himpunanmenggunakan linked list.Pembuatan struktur data adalah pembentukan tipe data lengkap yangmempunyai empat property berikut :1.Nama: Identifier tipe data2.Domain: Domain / himpunan semesta nilai di tipe data3.Konstanta (penyebutan anggota-anggotanya) : Cara penyebutanconverted by Web2PDFConvert.com

anggota-anggota tipe data4.Operasi-operasi terhadap tipe data itu (operator): Daftar operasiterhadap anggota tipe data sehingga kelakuan objek data sesuaispesifikasi.

\section{B. PEMBAHASAN / STUDI KASUS}

Dalam istilah ilmu komputer, sebuah struktur data adalah carapenyimpanan, penyusunan dan pengaturan data di dalam media penyimpanankomputer sehingga data tersebut dapat digunakan secara efisien.SedangkanData adalah representasi dari fakta dunia nyata. Fakta atau keterangantentang kenyataan yang disimpan, direkam atau direpresentasikan dalambentuk tulisan, suara, gambar, sinyal atau simbol.Konstanta digunakan untuk menyatakan nilai tetap sedangkan variabledigunakan dalam program untuk menyatakan nilai yang dapat berubahubahselang eksekusi berlangsung.Ada empat istilah data, yaitu:1.Tipe data adalah jenis atau macam data di dalam suatu variabledalam bahasa pemrograman.2.Objek data mengacu kumpulan elemen, D (domain).3.Representasi data : Suatu mapping dari struktur data 'd' ke suatuset ke struktur data ' $\mathrm{e}$ ' $(\mathrm{d}===\mathrm{e})$ misal bolean di representasikandalam 0 dan 1.4.Struktur data biasa dipakai untuk mengelompokan beberapainformasi yang terkait menjadi sebuah kesatuan.Dalam teknik pemrograman, struktur data berarti tata letak data yang berisi kolom-kolom data, baik itu kolom yang tampak oleh pengguna (user) atau pun 
kolom yang hanyadigunakan untuk keperluan pemrograman yang tidak tampak oleh pengguna.Setiap baris darikumpulan kolom-kolom tersebut dinamakan catatan (record). Lebar kolom untuk data dapatberubah dan bervariasi. Ada kolom yang lebarnya berubah secara dinamis sesuai masukandari pengguna, dan juga ada kolom yang lebarnya tetap. Dengan sifatnya ini, sebuahstruktur data dapat diterapkan untuk pengolahan database (misalnya untuk keperluan datakeuangan) atau untuk pengolah kata (word processor) yang kolomnya berubah secaradinamis. Contoh struktur data dapat dilihat pada berkas-berkas lembar-sebar (spreadsheet),pangkal-data (database), pengolahan kata, citra yang dipampat (dikompres), jugapemampatan berkas dengan teknik tertentu yang memanfaatkan struktur data.Secara garis besar type data dapat dikategorikan menjadi:Type data sederhana.Type data sederhana tunggal, misalnya Integer, real, boolean dankarakter.Type data sederhana majemuk, misalnyaStringStruktur Data, meliputi:converted by Web2PDFConvert.com

Struktur data sederhana, misalnya array dan record.Struktur data majemuk, yang terdiri dari:a)Linier : Stack, Queue, sertaList dan Multilistb)Non Linier : Pohon Biner dan GraphPemakaian struktur data yang tepat didalam proses pemrograman akan menghasilkanalgoritma yang lebih jelas dan tepat, sehingga menjadikan program secara keseluruhan lebihefisien dan sederhana.Struktur data yang standar yang biasanya digunakan dibidang informatika adalah:ØList linier (Linked List) dan variasinya ØMultilist ØStack

(Tumpukan)ØQueue

(Antrian)ØTree

Pohon)ØGraph ( G

Struktur data biasa dipakai untuk mengelompokan beberapainformasi yang terkait menjadi sebuah kesatuan.Dalam teknik pemrograman, struktur data berarti tata letak data yang berisi kolom-kolom data, baik itu kolom yang tampak oleh pengguna (user) atau pun kolom yang hanyadigunakan untuk keperluan pemrograman yang tidak tampak oleh pengguna.Setiap baris darikumpulan kolom-kolom tersebut dinamakan catatan (record). Lebar kolom untuk data dapatberubah dan bervariasi. Ada kolom yang lebarnya berubah secara dinamis sesuai masukandari pengguna, dan juga ada kolom yang lebarnya tetap. Dengan sifatnya ini, sebuahstruktur data dapat diterapkan untuk pengolahan database (misalnya untuk keperluan datakeuangan) atau untuk pengolah kata (word processor) yang kolomnya berubah secaradinamis. Contoh 
struktur data dapat dilihat pada berkas-berkas lembar-sebar (spreadsheet),pangkal-data (database), pengolahan kata, citra yang dipampat (dikompres), jugapemampatan berkas dengan teknik tertentu yang memanfaatkan struktur data.

\section{ID SECURITY}

QWTD4452377-ASP-5244107

\section{KESIMPULAN}

Struktur data merupakan salah satu bahan dasar pembuatan program.Pemakaian struktur data yang tepat di dalam proses pemrograman,

akanmenghasilkan algoritma yang jelas dan tepat sehingga menjadikan programsecara keseluruhan lebih sederhana. Array merupakan bagian dari strukturdata yaitu termasuk kedalam struktur data sederhana yang dapat di definisikansebagai pemesanan alokasi memory sementara pada komputer.Apabila kitamembuat program dengan data yang sudah kita ketahui batasnyamaka

kitamenggunakan Array (type data statis), namun apabila datanya belum kitaketahui batasnya maka gunakan pointer (type data dinamis).

\section{E. DISKUSI}

Saya bersama teman saya bernama M RIAN SAFEI mendiskusikan tentang materi ini dan Hasil diskusi dari materi ini adalah

Struktur data biasa dipakai untuk mengelompokan beberapainformasi yang terkait menjadi sebuah kesatuan.Dalam teknik pemrograman, struktur data berarti tata letak data yang berisi kolom-kolom data, baik itu kolom yang tampak oleh pengguna (user) atau pun kolom yang hanyadigunakan untuk keperluan pemrograman yang tidak tampak oleh pengguna.Setiap baris darikumpulan kolom-kolom tersebut dinamakan catatan (record). Lebar kolom untuk data dapatberubah dan bervariasi. Ada kolom yang lebarnya berubah secara dinamis sesuai masukandari pengguna, dan juga ada kolom yang lebarnya tetap. Dengan sifatnya ini, sebuahstruktur data dapat diterapkan untuk pengolahan database (misalnya untuk keperluan datakeuangan) atau untuk pengolah kata (word processor) yang kolomnya berubah secaradinamis. Contoh struktur data dapat dilihat pada berkas-berkas lembar-sebar (spreadsheet),pangkal-data (database), pengolahan kata, citra yang dipampat (dikompres), jugapemampatan berkas dengan teknik tertentu 
yang memanfaatkan struktur data.

\section{F. REFERENCE}

[1] O. M. Febriani and A. S. Putra, "Sistem Informasi Monitoring Inventori Barang Pada Balai Riset Standardisasi Industri Bandar Lampung," J. Inform., vol. 13, no. 1, pp. 90-98, 2014.

[2] A. S. Putra, "Paperplain: Execution Fundamental Create Application With Borland Delphi 7.0 University Of Mitra Indonesia," 2018.

[3] A. S. Putra, "2018 Artikel Struktur Data, Audit Dan Jaringan Komputer," 2018.

[4] A. S. Putra, "ALIAS MANAGER USED IN DATABASE DESKTOP STUDI CASE DB DEMOS." A. S. Putra, "COMPREHENSIVE SET OF PROFESSIONAL FOR DISTRIBUTE COMPUTING."

[6] A. S. Putra, "DATA ORIENTED RECOGNITION IN BORLAND DELPHI 7.0."

[7] A. S. Putra, "EMBARCADERO DELPHI XE 2 IN GPUPOWERED FIREMONKEY APPLICATION."

[8] A. S. Putra, "HAK ATAS KEKAYAAN INTELEKTUAL DALAM DUNIA TEKNOLOGY BERBASIS REVOLUSI INDUSTRI 4.0."

[9] A. S. Putra, "IMPLEMENTASI PERATURAN

PERUNDANGAN UU. NO 31 TAHUN 2000 TENTANG
DESAIN INDUSTRI BERBASIS INFORMATION TECHNOLOGY."

[10]

$\begin{array}{lr}\text { A. S. } & \text { Putra, } \\ \text { "IMPLEMENTATION } & \text { OF } \\ \text { PARADOX DBASE." } & \end{array}$

A. S. Putra, "IMPLEMENTATION OF TRADE SECRET CASE STUDY SAMSUNG MOBILE PHONE."

A. S. Putra, "IMPLEMENTATION

PATENT FOR APPLICATION WEB BASED CASE STUDI WWW. PUBLIKLAMPUNG. COM."

[13] A. S. Putra, "IMPLEMENTATION SYSTEM FIRST TO INVENT IN DIGITALLY INDUSTRY."

[14] A. S. Putra, "MANUAL REPORT \& INTEGRATED DEVELOPMENT

ENVIRONMENT BORLAND DELPHI 7.0."

[15] A. S. Putra, "PATENT AS RELEVAN SUPPORT RESEARCH."

[16] A. S. Putra, "PATENT FOR RESEARCH STUDY CASE OF APPLE. Inc."

[17] A. S. Putra, "PATENT PROTECTION FOR APPLICATION INVENT."

[18] A. S. Putra, "QUICK REPORT IN PROPERTY PROGRAMMING."

[19] A. S. Putra, "REVIEW CIRCUIT LAYOUT COMPONENT

REQUIREMENT ON ASUS NOTEBOOK."

[20] A. S. Putra, "REVIEW TRADEMARK PATENT FOR 
INDUSTRIAL TECHNOLOGY BASED 4.0."

[21] A. S. Putra, "TOOLBAR COMPONENT PALLETTE IN OBJECT ORIENTED PROGRAMMING.'"

[22] A. S. Putra, "WORKING DIRECTORY SET FOR PARADOX 7."

[23] A. S. Putra, "ZQUERY CONNECTION IMPLEMENTED PROGRAMMING STUDI CASE PT. BANK BCA Tbk."

[24] A. S. Putra, D. R. Aryanti, and I. Hartati, "Metode SAW (Simple Additive Weighting) sebagai Sistem Pendukung Keputusan Guru Berprestasi (Studi Kasus: SMK Global Surya)," in Prosiding Seminar Nasional Darmajaya, 2018, vol. 1, no. 1, pp. 85-97.

[25] A. S. Putra and O. M. Febriani, "Knowledge Management Online Application in PDAM Lampung Province," in Prosiding International conference on Information Technology and Business (ICITB), 2018, pp. 181-187.

[26] A. S. Putra, O. M. Febriani, and B. Bachry, "Implementasi Genetic Fuzzy System Untuk Mengidentifikasi Hasil Curian Kendaraan Bermotor Di Polda Lampung," SIMADA (Jurnal Sist. Inf. dan Manaj. Basis Data), vol. 1, no. 1, pp. 21-30, 2018.

[27] A. S. Putra, H. Sukri, and K. Zuhri, "Sistem Monitoring Realtime Jaringan Irigasi Desa (JIDES) Dengan Konsep Jaringan Sensor Nirkabel,"
IJEIS (Indonesian J. Electron. Instrum. Syst., vol. 8, no. 2, pp. 221-232.

[28] D. P. Sari, O. M. Febriani, and A. S. Putra, "Perancangan Sistem Informasi SDM Berprestasi pada SD Global Surya," in Prosiding Seminar Nasional Darmajaya, 2018, vol. 1, no. 1, pp. 289-294. 